\title{
COMPARING THE EFFECTIVENESS OF INFORMATION FRAMING STRATEGY ON UTILITARIAN AND HEDONIC FOOD PRODUCT PACKAGING
}

\author{
Sony Kusumasondjaja ${ }^{* 1}$ \\ ${ }^{*}$ Faculty of Economics and Business, Airlangga University \\ Jl. Airlangga 4-6, Surabaya 60286
}

\begin{abstract}
The increasing adoption of framing strategy among food marketers and advertisers generates inquiries about the effectiveness of the strategy. Product messages with different framing strategy are expected to stimulate different consumer responses. This research investigates the difference of consumer attitude and purchase intention towards the framed product when consumers are exposed to food labels with different types of food product (hedonic vs utilitarian) using different framing strategy (positive vs negative). A lab experimental design was prepared involving 160 participants. Chocolate was examined to represent hedonic product while packaged milk was used as utilitarian product. Data were analyzed using ANOVA and multiple linear regression. Findings suggested that the effectiveness of framing strategy was moderated by product type. Positive framing was found to be more effective for hedonic food products, while for utilitarian food product, it was more favorable to adopt negative framing.
\end{abstract}

Keywords: framing, label, hedonic, utilitarian, food marketing

\begin{abstract}
Abstrak: Meningkatnya penggunaan strategi pembingkaian di kalangan pemasar dan pengiklan makanan memunculkan pertanyaan atas efektivitas strategi tersebut. Informasi tentang produk yang menggunakan strategi pembingkaian yang berbeda diduga memunculkan respon konsumen yang berbeda pula. Penelitian ini mengkaji perbedaan persepsi kualitas, sikap dan niat beli konsumen saat dihadapkan pada label produk makanan dengan jenis yang berbeda (utilitarian dan hedonis) dengan menggunakan strategi framing yang berbeda (positif dan negatif). Desain eksperimental laboratorium dirancang dengan melibatkan 160 orang partisipan. Permen coklat dipilih untuk mewakili produk hedonis sedangkan susu dalam kemasan digunakan untuk mewakili produk utilitarian. Data diolah dengan menggunakan ANOVA dan regresi linier sederhana. Hasil penelitian menyimpulkan bahwa efektivitas strategi pembingkaian yang digunakan pada label produk tergantung dari jenis produk yang dibingkai. Strategi pembingkaian positif lebih menguntungkan bila diterapkan pada produk makanan hedonis sedangkan pembingkaian negatif lebih efektifjika digunakan produk makanan utilitarian.
\end{abstract}

Kata kunci: pembingkaian, label, hedonis, utilitarian, pemasaran makanan

\footnotetext{
${ }^{1}$ Corresponding author:

Email: s.kusumasondjaja@feb.unair.ac.id
} 


\section{INTRODUCTION}

Persuasive message on marketing communication activity plays an important role in encouraging consumers to develop particular attitudinal or behavioral responses. When being exposed to product information on advertising or product label, consumers may respond differently when the information is framed in a different way. Message framing strategy generally can be defined as message or information creation strategy performed by framing the content based on certain aspects and presenting it in such a way that may generate expected responses from the recipients (van Kleef et al. 2005). The terminology of framing is introduced by Tversky and Kahneman (1985) which is then expanded to different research context; including psychology, advertising, political science, journalism, or food science.

Framing strategy has been widely implemented by food products; both in their advertising and packaging label. Some of the most popular examples of the framing strategy adopted by food products are the presentation of information about fat or sugar ingredients in a milk. Marketers of cooking oil products in Indonesia suggest to their consumers; through advertising and packaging labels, that one indicator that should be considered in choosing cooking oil is the frequency of filtration during its production process.

Framing strategy can be implemented by creating positive-negative or gain-loss framing. Positivenegative framing is conducted by emphasizing the positive or negative aspects of one of the product attributes(Mittelman etal.2014). For example, a yoghurt product named Yoplat Original uses a positive framing strategy by stating $100 \%$ fat free in its packaging label to highlight the message of being a fat-free product. On the other hand, another yoghurt product named Light n' Fit use negative framing strategy by declaring $0 \%$ fat on its packaging to stress the message of fat ingredients in the product. There is no actual difference in meanings in those two claims as both suggest that the yoghurts do not contain fat. Similarly, gain-loss framing can be done by delivering information or message by emphasizing the potential benefits that can be obtained or the potential loss that should be avoided when consumers or audiences are willing to follow the advice suggested in the information or message. For example, health message using gain framing about the importance of calcium consumption is delivered by saying that sufficient calcium consumption reduces the risk of getting osteoporosis. Meanwhile, when using loss framing, the message should be written that insufficient calcium consumption increases the risk of getting osteoporosis. Although both statements about the calcium consumption basically share the same meaning. Prior studies conducted extensively found that those two ways of stating similar content with different framing have different impact on consumer cognitive process (Gerend \& Sheperd, 2013; Just \& Wasink, 2014; Holton et al. 2014; Wasink \& Pope, 2015; Chang et al. 2015).

Prior studies found inconsistent findings about how message should be framed, whether it should be positive or negative, gain or loss. Some research posits that positive or gain framing generates better responses. For example, a study by Gerend and Sheperd (2013) concludes that health information on a brochure about the importance of calcium consumption on health that is gain-framed results higher consumption behavior tendency than the same information delivered using loss framing strategy. Another research finds that food product information framed negatively helps consumers to think that the product has higher risks than the other food product that has information presented with positive framing (Mitchell et al. 2015). Similar results is presented by Segev et al. (2015) suggesting that consumers respond more positively to green product advertisements when the ads highlight the potential benefits if the audience follows the advice mentioned in the ads. However, some other works discover that negative or loss framing generates better consumer responses. For instance, Moon et al. (2016) found that green product advertisement that is negatively framed and highlights the loss consumers will have to take when fails to follow the advice.

A study by de Bruijn (2016) also found that health information framed emphasizing on negative consequences or loss from not following health advice drives more significant behavioral change compared to the one stressing on positive impact from following the suggestion. Interestingly, Abrams (2015) postulates that the use of positive or negative framing on food product label elicits indifferent consumer responses. Similarly, Jin and Han (2014) also argue that different message framing strategy does not result in different responses when the target audiences have a strong understanding on the issue being discussed and framed. 
The inconsistent findings in prior studies generate the needs to do similar research on the context of food products in Indonesia. Moreover, although studies on framing strategy has been conducted extensively on different settings, the effectiveness of framing strategy on utilitarian and hedonic food products comparing are still underexplored. The lack of literature on this issue calls for more investigations to assist food and beverage firms utilizing framing strategy in their marketing communication content in order to gain competitive advantage. The different characteristics behind consumer situation and motivation related to those two types of product require marketers to consider how to communicate them in order to obtain desired consumer responses. Considering the great number of food and beverage marketed in Indonesia, understanding on how to create effective message for marketing communication activity is crucial in crafting competitive advantage.

Based on the phenomena and literature review explained above, this research aims at comparing the effectiveness of positive and negative information framing strategy on product packaging, both for utilitarian and hedonic products, on perceived quality and attitude towards the product. It also intends to confirm the effect of perceived quality and attitude toward the product on consumer intention to purchase food product. The scope of this research is limited to the context of food and beverage products that serve utilitarian and hedonic motivation in Indonesian context.

\section{METHODS}

Based on the research problems intended to answer, this research can be categorized as an explanatory research using experimental design aimed at investigating causal relationships between manipulated variables, framing strategy (positive and negative) and product types (utilitarian and hedonic), and measured variables (perceived quality and purchase intention). This study adopted 2 (positive vs negative framing) x 2 (utilitarian vs hedonic product) between-subject factorial design.

To manipulate the experimental variables, food products used as stimuli were pre-tested by observing and identifying food products using positively or negatively framed packaging label placed on the shelves at major supermarkets in Surabaya. All food products identified from the pre-test stage were grouped based on their types of utilitarian or hedonic product. Based on the pre-test involving 40 participants, packaged milk and chocolate candy were selected as utilitarian and hedonic product consecutively to be examined in this study. For both utilitarian and hedonic items, products with packaging design that was hardly associated with particular brand were selected. Their packaging labels were then manipulated, one label with positively framed information and the other was framed negatively. The information displayed on the product label were " $99 \%$ fat free - tasty" (positive framing) and " $1 \%$ fat - not getting fat" (negative framing).

Research instrument used in this study consists of measurement items for dependent variables adapted from prior studies. Perceived quality construct was measured by 4 measurement items borrowed from Wang (2013) and Ha and Jang (2010). Attitude towards the product was assessed by 4 measurement items adapted from Lee and Yun (2015). Meanwhile, purchase intention was measured using 5 measurement items adapted from Das (2014) and Wang et al. (2012). All items were assessed using 7-point Likert scale, with 1 representing strongly disagree and 7 for strongly agree.

This research involved 160 undergraduate student participants recruited from one major state university in Surabaya i.e. the undergraduate students in December 2016. Random assignment was used to Participants' involvement in this study was arranged on random assignment basis. There were 40 participants assigned to each treatment group where they were exposed to hedonic product with positively framed label, hedonic product with negatively framed label, utilitarian product with positively framed label, and utilitarian product with negatively framed label. After completing demographic profile questions, they received one of the four stimuli. They were asked to hold the food product tested and observe its label and were pleased to complete the questionnaire. All participants received utilitarian and hedonic food products with identical package and label. The only difference was the words used to frame the information. Data obtained from the participants were analyzed using Analysis of Variance (ANOVA) to test the differences in responses to the stimuli and Multiple Regression to test the effect of perceived quality and attitude towards the product on purchase intention. Both statistical tools were operated using SPSS version 18. 
In perception formation process, message framing on the product label is the stimuli that will be responded by consumers' sense. Solomon (2014) explained that attribute framing is a sight; one of the sensory stimuli; received by the eyes that generates exposure and attention before interpretation process begins. Another thought explaining the relationships between message framing on product packaging label is proposed by Borin et al. (2011) suggesting that product attribute in packaging can influence consumer perception of product quality. Consumer perception of product quality is stimulated by intrinsic and extrinsic attributes provided by the marketers (Lahteenmakki et al. 2010). Yan et al. (2010) confirmed that consumer perception toward positively framed information can be formed because positive framing helps consumer to associate the product with good memory. On the other hand, negative framing calls for negative association from the memory and forms negative perception in consumers' mind. Because the cognitive process the consumers have to go through when being exposed to information with positive and negative framing is different, their responses to the information are also different.

Consumers make purchase decisions on utilitarian and hedonic food products by going through different cognitive processes. Utilitarian products are purchased by consumers based on the urge to satisfy basic and practical needs. Meanwhile, hedonic products are acquired to fulfill hedonic or tertiary needs. For that reason, consumers tend to decide to buy utilitarian products when their absence leads to negative consequences for them (negative framing) and purchase hedonic products when adopting them results positive consequences for them (positive framing).

When consumers develop positive perception toward one particular product, the tendency to generate positive response to the product is usually high. Normally consumers formulate perception toward product by using stimuli or cues that are extrinsically recognizable through their senses; such as price, packaging forms, labels, product dimensions or sizes, and some other factors (Saens-Navajaz et al. 2013). In another situation, consumers can also form perception towards particular product based on intrinsic stimuli or cues that are difficult to recognize; such as ingredients (Walters \& Long, 2012). When consumer perception is formed based on extrinsic cues; such as labels on product packaging, intention to purchase the product is developed as well. The better the consumer perception toward the product, the greater the consumer intention to purchase it (Banovic et al. 2010; Walters \& Long, 2012). Figure 1 depicts the research framework.

Based on the explanation and research framework presented above, these following hypotheses were proposed:

H1: Food product labelled with positive framing is perceived as having better quality than the one labelled with negative framing

H2: Food product labelled with positive framing generates more favorable attitude toward the product than the one labelled with negative framing

H3: Hedonic food product labelled with positive framing is perceived as having better quality than the one labelled with negative framing

H4: Utilitarian food product labelled with negative framing is perceived as having better quality than the one labelled with positive framing

H5: Hedonic food product labelled with positive framing generates more favorable attitude toward the product than the one labelled with negative framing

H6: Utilitarian food product labelled with negative framing generate more favorable attitude towards the product than the one labelled with positive framing

H7: The better the perceived quality of product, the higher the consumer intention to purchase the product

H8: The more favorable the attitude towards the product, the greater the consumer intention to purchase the product.

\section{RESULTS}

Participants involved in this study were undergraduate students from the major state university in Surabaya. There were 160 participants aged 19-21 years old and fairly distributed in gender. $83 \%$ of the participants stated that they consumed the food products being used as stimuli at least once in a month, indicating high level of product familiarity. Generally, participants' demographic profile shows good level of homogeneity that suits with the needs of this study. 


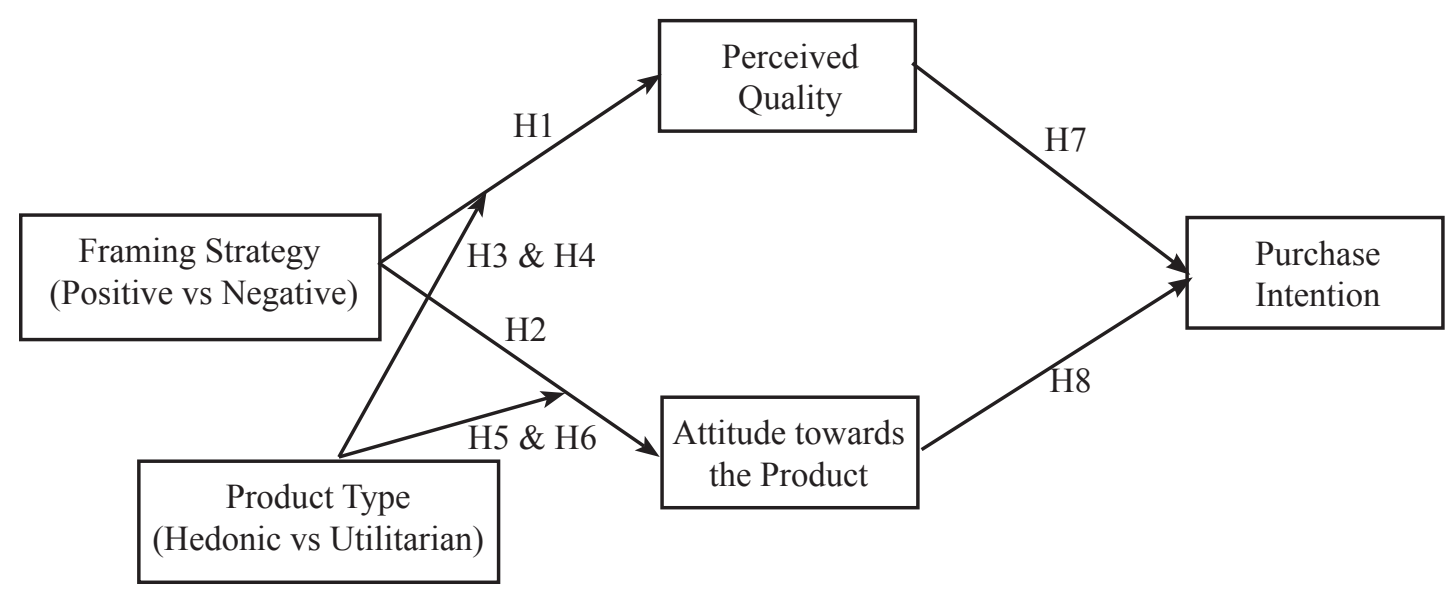

Figure 1. Research framework

Check manipulation was conducted for both product types and message framing on the labels to ensure that target participants understood the stimuli as they were intended to be. Two questions were asked to confirm whether packaged milk was understood as utilitarian product and if chocolate candy was considered as hedonic product. They were also asked whether the stimuli designed for the experiment were confirmed as positive or negative framing. The results from manipulation check validated that all stimuli designed for this study were understood as they were intended to be.

For measurement items in the questionnaire used for assessing the two dependent variables, the construct reliability and validity of the items were examined using Cronbach's alpha and correlation coefficient scores. The results showed that all measurement items had coefficient scores significantly correlated to the total score with level of significance 0.05 indicating their validity. All constructs used in this study obtained Cronbach's alpha scores higher than $0.07 ; 0.923$ for perceived quality, 0.898 for attitude toward the product, and 0.917 for purchase intention; indicating good level of internal consistency.

Statistical examination processes were started by positioning message framing strategy as independent variable while perceived quality and attitude toward the product were treated as dependent variables and analyzing them by using ANOVA. The next stage was performed by positioning product types as moderating variables on the relationships between message framing and perceived quality and the one between message framing and attitude toward the product and analyzing those relationships by using ANOVA. The final stage involved multiple regression to examine causal relationships among perceived quality, attitude toward the product, and purchase intention.

The results suggest that the main effect of message framing strategy on perceived quality was significant $(\mathrm{F}=1073.53, \mathrm{p}<.0 .1, \omega 2=0.023)$ indicating that product label presented with positive framing generates better perceived quality $(\mathrm{M}=5.778, \mathrm{SD}=0.42)$ than the one presented with negative framing $(\mathrm{M}=4.856, \mathrm{SD}=0.59)$. Meanwhile, the hypothesized main effect of message framing strategy on attitude toward the product was also supported $(\mathrm{F}=718.91, \mathrm{p}<0.01, \omega 2=0.037)$ indicating that product label presented with positive framing generates more favorable attitude $(\mathrm{M}=5.780, \mathrm{SD}=0.401)$ than the one presented with negative framing $(\mathrm{M}=5.002$, $\mathrm{SD}=0.309$ ). These results are presented in Table 1 . Therefore, hypothesis 1 and 2 were supported.

Further analysis was conducted to test the effectiveness of message framing strategy between different product types. The interaction effects between message framing and product types were confirmed; both for perceived quality $(\mathrm{F}(1,180)=355.894, \mathrm{p}<0.21, \omega 2=0.01)$ and attitude towards the product $(\mathrm{F}(1,180)=420.030$, $\mathrm{p}<0.17, \omega 2=0.05)$. Hedonic food product with positivelyframed label generates better perceived quality than the one with negatively-framed label. This result supports hypothesis 3. Meanwhile, utilitarian food product with negatively-framed label shows better perceived quality than the one with positively-framed label. This finding validates hypothesis 4 . Similar findings are shown for attitude toward the product. Hedonic food product with positively-framed label generates more favorable attitude than the one with negatively-framed label. This result supports hypothesis 5. Meanwhile, utilitarian 
food product with negatively-framed label shows better attitude than the one with positively-framed label. Hence, hypothesis 6 is supported. Table 2 explains the test results for hypothesis 3 to 6 .

The causal relationships among perceived quality, attitude towards the product, and intention to purchase food product were then examined. Results from multiple regression analysis show that perceived quality $(\mathrm{t}(161)=1,973, \mathrm{p}=0.041)$ and attitude towards the product $(\mathrm{t}(161)=1,318, \mathrm{p}=0.009)$ have a significant positive influence on purchase intention with the level of significance 0.05 . Table 4 presents the regression coefficients for all dependent variables examined.

As shown in Table 5, the results of regression test suggest that the impacts of perceived quality and attitude towards the product on purchase intention were confirmed significant $(\mathrm{F}(2,161)=34,611, \mathrm{p}=0.000)$. Hence, hypotheses 7 and 8 were supported.
Those findings indicate that the effectiveness of message framing strategy on product label depends on the type of the product being framed. Food product labelled with positive framing is generally responded more positively than the one with negative framing when the food product is categorized as hedonic foods. Conversely, food product labelled with negative framing is generally responded more positively than the one with positive framing when the food product is categorized as utilitarian foods. These findings are consistent with what prior studies have suggested (Raghunatan et al. 2006; Garg et al. 2007) that hedonic food product tends to be responded more positively if the information about it emphasizes on the potential benefit offered to its consumers. On the contrary, Van Kleef et al. (2005) and Van Wezemael et al. (2014) argue that utilitarian food product is more likely to be responded positively when the product information on the label highlights on the potential loss that can be avoided if consumers purchase the product.

Table 1. The results of main effect

\begin{tabular}{lcccccc}
\hline \multirow{2}{*}{ Independent variables } & \multicolumn{3}{c}{ Perceived quality } & \multicolumn{3}{c}{ Attitude towards the product } \\
\cline { 2 - 7 } & Mean & $\mathrm{F}$ & Sig & Mean & F & Sig. \\
\hline Message framing strategy & & & & & & \\
Positive framing & 5.778 & \multirow{2}{*}{1073.53} & 0.000 & 5.780 & 718.91 & 0.000 \\
Negative framing & 4.856 & & & 5.002 & & \\
\hline
\end{tabular}

Table 2. The results for interaction effect

\begin{tabular}{llcccccc}
\hline \multirow{2}{*}{ Independent variables } & \multicolumn{3}{c}{ Perceived quality } & \multicolumn{3}{c}{ Attitude towards the product } \\
\cline { 3 - 7 } & & Mean & F & Sig & Mean & F & Sig. \\
\hline Positive & Hedonic & 6.111 & 355.894 & 0.000 & 5.780 & 420.030 & 0.000 \\
Framing & Utilitarian & 5.444 & & & 5.002 & & \\
Negative & Hedonic & 5.053 & & & 5.689 & \\
Framing & Utilitarian & 4.658 & & & 5.098 & & \\
\hline
\end{tabular}

Table 4. Regression coefficients of the impact of perceived quality, attitude towards the product, and purchase intention

\begin{tabular}{|c|c|c|c|c|c|c|}
\hline & \multirow{2}{*}{ Model } & \multicolumn{2}{|c|}{ Unstandardized coefficients } & \multirow{2}{*}{$\frac{\text { Standardized coefficients }}{\text { Beta }}$} & \multirow{2}{*}{$\mathrm{T}$} & \multirow{2}{*}{ Sig. } \\
\hline & & Beta & Std. Error & & & \\
\hline \multirow{3}{*}{1} & (Constant) & 2.491 & 2.79 & & 8.923 & 0.000 \\
\hline & Quality & 0.241 & 1.22 & 0.324 & 1.973 & 0.041 \\
\hline & Attitude & 0.175 & 1.33 & 0.216 & 1.318 & 0.009 \\
\hline
\end{tabular}

a. Dependent variable: Purchase intention 
Table 5. Results of multiple regression analysis on the impact of perceived quality and attitude toward the product on purchase intention

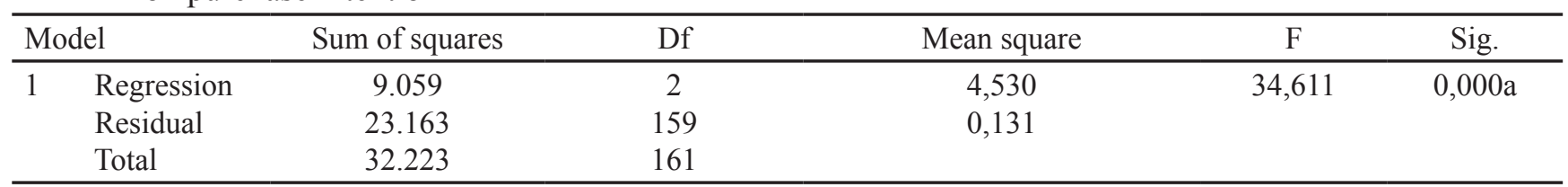

a. Independent variables: perceived quality, attitude toward the product; b. Dependent variable: purchase intention

Hedonic product is commonly purchased following consumers' urge to experience pleasure and happiness, while utilitarian product is mainly consumed to satisfy the needs to complete functional daily tasks (Bart et al. 2014). Chocolate candy is consumed to attain enjoyment and pleasure because its function serves tertiary needs. Hence, when evaluating the product packaging label of chocolate candy, consumers tend to pay more attention on potential benefit attained when consuming the product, for example, enjoying tasty chocolate candy that helps them to relax. Meanwhile, packaged milk is normally consumed just to quench thirst or keep up the health without any hedonic motivation. As a result, consumers tend to choose products that help them avoiding from any loss if not consuming the product.

Another finding suggests that the appropriate message framing decision is important as it is found that consumer perception of perceived quality of the market offering will determine whether or not consumers develop intention to purchase (Wang, 2013). As postulated by Sari and Setiaboedhi (2017), when consumers trust the quality of the food product, they are more likely to form purchase intention. Moreover, when food product is labelled with appropriate framing, favorable consumer attitude toward the product is formed. The favorable attitude will eventually have an impact on intention to buy (Rubio et al. 2014).

\section{Managerial Implications}

Product packaging and label have been widely adopted by many food products as one of the important marketing communication tools; especially to help persuade consumers at the point of purchase. Investigating the role of message framing and product types, this research contributes to strengthen existing marketing literature on effective message framing strategies for food products in Indonesia. This study clarifies that effective message framing implemented may develop consumer perception of the product quality and attitude toward the food product that lead to purchase intention.
This is considered as an important issue considering the lack of empirical research finding on message framing strategy on food and beverage product in Indonesian context.

Findings of this study also offer managerial contributions for food and beverage firms in Indonesia. They need to take into consideration product types when designing message framing strategy for the product labels, otherwise its effectiveness tends to weaken. Considering packaging and label are the marketing communication tools which build the closest interaction with consumers at the point of purchase, the mistake in choosing the most suitable framing strategy for the product may result in negative impact on sales performance in the market.

\section{CONCLUSIONS AND RECOMMENDATIONS}

\section{Conclusion}

Results show that the effectiveness of framing strategy adopted for food product depends on the type of product being framed. While product label using positive framing is more effective for hedonic food product in eliciting better perceived quality and more favorable attitude, negative framing works better for utilitarian one.

\section{Recommendations}

Regardless of the significant contributions offered, there are some limitations in this study that need to be considered for further study. One limitation this research faces is in the choice of experimental design to evaluate the causality among variables. The experimental method limits generalizability of the findings. Although food products investigated in this study are widely available in the market, generalization of the results to a wider population should be done carefully. This study observes only one moderating factor that is a product type; while 
there are many elements in the product packaging that may have impacts on consumer responses, such as familiarity or visual design (Kauppinen-Räisänen et al. 2012). Future research should pay more attention at other factors in the product packaging that may affect consumer responses.

\section{REFERENCES}

Abrams KM. 2015. Loss aversion and regulatory focus effects in the absence of numbers: qualitatively framing equivalent messages on food labels. Journal of Applied Communications 99(3):2137. https://doi.org/10.4148/1051-0834.1054.

Banović M, Grunert KG, Barreira, M. M., Fontes, M. A. 2010. Consumers' quality perception of national branded, national store branded, and imported store branded beef. Meat Science 84(1):54-65. https://doi.org/10.1016/j.meatsci.2009.08.037.

Bart Y, Stephen AT, Sarvary M. 2014. Which products are best suited to mobile advertising? A field study of mobile display advertising effects on consumer attitudes and intentions. Journal of Marketing Research 51(3):270-285. https://doi. org/10.1509/jmr.13.0503.

Borin N, Cerf DC, Krishnan R. 2011. Consumer effects of environmental impact in product labeling. Journal of Consumer Marketing 28(1):76-86. https://doi.org/10.1108/07363761111101976.

Chang H, Zhang L, Xie GX. 2015. Message framing in green advertising: The effect of construal level and consumer environmental concern. International Journal of Advertising 34(1):158176. https://doi.org/10.1080/02650487.2014.99 4731.

Das G. 2014. Linkages of retailer awareness, retailer association, retailer perceived quality and retailer loyalty with purchase intention: a study of Indian food retail brands. Journal of Retailing and Consumer Services 21(3):284-292. https:// doi.org/10.1016/j.jretconser.2014.02.005.

de Bruijn GJ, Spaans P, Jansen B, van't Riet J. 2016. Testing the effects of a message framing intervention on intentions towards hearing loss prevention in adolescents. Health Education Research31(2):161-170.https://doi.org/10.1093/ her/cyw006.

Garg N, Wansink B, Inman JJ. 2007. The influence of incidental affect on consumers' food intake. Journal of Marketing 71(1):194-206. https:// doi.org/10.1509/jmkg.71.1.194.

Gerend MA, Shepherd MA. 2013. Message framing, it does a body good: Effects of message framing and motivational orientation on young women's calcium consumption. Journal of Health Psychology 18(10):1296-1306. https://doi. org/10.1177/1359105312463587.

Ha J, Jang SS. 2010. Effects of service quality and food quality: The moderating role of atmospherics in an ethnic restaurant segment. International Journal of Hospitality Management 29(3):520 529. https://doi.org/10.1016/j.ijhm.2009.12.005.

Holton A, Lee N, Coleman R. 2014. Commenting on health: A framing analysis of user comments in response to health articles online. Journal of Health Communication 19(7):825-837. https:// doi.org/10.1080/10810730.2013.837554.

Jin HJ, Han DH. 2014. Interaction between message framing and consumers' prior subjective knowledge regarding food safety issues. Food Policy 44:95-102. https://doi.org/10.1016/j. foodpol.2013.10.007.

Just DR, Wansink B. 2014. One man's tall is another man's small: how the framing of portion size influences food choice. Health Economics 23(7):776-791.https://doi.org/10.1002/ hec.2949.

Kauppinen-Räisänen H, Owusu RA, Abeeku BB. 2012. Brand salience of OTC pharmaceuticals through package appearance. International Journal of Pharmaceutical and Healthcare Marketing 6(3):230-249. https://doi. org/10.1108/17506121211259403.

Lähteenmäki L, Lampila P, Grunert K, Boztug Y, Ueland Ø, Åström A, Martinsdóttir E. 2010. Impact of health-related claims on the perception of other product attributes. Food Policy 35(3):230-239. https://doi.org/10.1016/j.foodpol.2009.12.007.

Lee HJ, Yun ZS. 2015. Consumers' perceptions of organic food attributes and cognitive and affective attitudes as determinants of their purchase intentions toward organic food. Food Quality and Preference 39:259-267. https://doi. org/10.1016/j.foodqual.2014.06.002.

Mitchell VW, Bakewell C, Jackson P, Heslin C. 2015. How message framing affects consumer attitudes in food crises. British Food Journal 117(8):2200-2211. https://doi.org/10.1108/BFJ01-2015-0015.

Mittelman M, Andrade EB, Chattopadhyay A, Brendl CM. 2014. The offer framing effect: choosing 
single versus bundled offerings affects variety seeking. Journal of Consumer Research 41(4):953-964. https://doi.org/10.1086/678193.

Moon S, Bergey PK, Bove LL, Robinson S. 2016. Message framing and individual traits in adopting innovative, sustainable products (ISPs): Evidence from biofuel adoption. Journal of Business Research 69(9):3553-3560. https:// doi.org/10.1016/j.jbusres.2016.01.029.

Raghunathan R, Naylor RW, Hoyer WD. 2006. The unhealthy tasty intuition and its effects on taste inferences, enjoyment, and choice of food products. Journal of Marketing 70(4):170-184. https://doi.org/10.1509/jmkg.70.4.170.

RubioN, OubiñaJ, VillaseñorN.2014. BrandawarenessBrand quality inference and consumer's risk perception in store brands of food products. Food Quality and Preference 32: 289-298. https://doi. org/10.1016/j.foodqual.2013.09.006.

Sáenz-Navajas MP, Campo E, Sutan A, Ballester J, Valentin D. 2013. Perception of wine quality according to extrinsic cues: The case of Burgundy wine consumers. Food Quality and Preference 27(1):44-53.

Sari H, Setiaboedhi AP. 2017. Faktor-faktor yang memengaruhi minat beli pangan organik melalui situs online. Jurnal Manajemen \& Agribisnis 14(1):54-64.http://dx.doi.org/10.17358/ jma.14.1.54.

Segev S, Fernandes J, Wang W. 2015. The effects of gain versus loss message framing and point of reference on consumer responses to green advertising. Journal of Current Issues \& Research in Advertising 36(1):35-51. https:// doi.org/10.1016/j.foodqual.2012.06.006.

Solomon MR. 2014. Consumer Behavior: Buying, Having, and Being 10th Ed. Engelwood Cliffs. NJ: Prentice Hall.

Tversky A, Kahneman D. 1985. The framing of decisions and the psychology of choice. In Environmental Impact Assessment, Technology Assessment, and Risk Analysis (pp. 107-129). Springer Berlin Heidelberg.

Van Kleef E, van Trijp HC, Luning P. 2005. Functional foods: health claim-food product compatibility and the impact of health claim framing on consumer evaluation. Appetite 44(3): 299-308. https://doi.org/10.1016/j.appet.2005.01.009.

Van Wezemael L, Caputo V, Nayga RM, Chryssochoidis G, Verbeke W. 2014. European consumer preferences for beef with nutrition and health claims: A multi-country investigation using discrete choice experiments. Food Policy 44:167-176.https://doi.org/10.1016/j. foodpol.2013.11.006.

Van't Riet J, Werrij MQ, Nieuwkamp R, de Vries H, Ruiter RA. 2013. Message frame and selfefficacy influence the persuasiveness of nutrition information in a fast-food restaurant. Food Quality and Preference 29(1):1-5. https://doi. org/10.1016/j.foodqual.2013.01.007.

Walters A, Long M. 2012. The effect of food label cues on perceptions of quality and purchase intentions among high-involvement consumers with varying levels of nutrition knowledge. Journal of Nutrition Education and Behavior 44(4):350 354. https://doi.org/10.1016/j.jneb.2011.08.008.

Wang E. 2013. The influence of visual packaging design on perceived food product quality, value, and brand preference. International Journal of Retail \& Distribution Management 41(10):805816. https://doi.org/10.1108/IJRDM-12-20120113.

Wang CL, Li D, Barnes BR, Ahn J. 2012. Country image, product image and consumer purchase intention: Evidence from an emerging economy. International Business Review 21(6):1041-1051. https://doi.org/10.1016/j.ibusrev.2011.11.010.

Wansink B, Pope L. 2015. When do gain-framed health messages work better than fear appeals? Nutrition Reviews 73(1):4-11. https://doi. org/10.1093/nutrit/nuu010.

Werle CO, Wansink B, Payne CR. 2015. Is it fun or exercise? The framing of physical activity biases subsequent snacking. Marketing Letters 26(4):691-702. https://doi.org/10.1007/s11002014-9301-6.

Yan C, Dillard JP, Shen F. 2010. The effects of mood, message framing, and behavioral advocacy on persuasion. Journal of Communication 60(2):344-363. https://doi.org/10.1111/j.14602466.2010.01485.x. 